\title{
RESEARCH AND DEVELOPMENT IN \\ THE ELEMENTARY SCHOOL ON MAKASSARESE LANGUAGE LEARNING MATERIALS BASED ON CHARACTER BUILDING CONCEPT $^{1}$
}

\author{
Sitti Rabiah $^{2}$ \\ Faculty of Letter \\ Universitas Muslim Indonesia
}

\begin{abstract}
Elementary school students are an asset of the Indonesian nation that very valuable to be maintained and developed with a positive character values that come from the family, school, society and nation. Character building for the youth generation is now a matter of urgency and decisive for the future of the nation toward Golden Generation in 2045. In this period, the generation who are now on early childhood education, primary education, secondary education, and higher education will enter productive age that determines the strategic role of this nation. Especially for elementary school age, they were aged 6-14 years old now, will be aged 39-47 years old in the year of 2045 and this means that they will enter the glorious period of their development. In order to develop this golden generation, it is necessary to reform the education sector which plays an important role to set up and direct the superior human resources and productive then mastery and develop science, technology and art are needed in this globalization era. One of the way to do that the integration of the characters values into Makassarese language learning materials. This learning materials is expected to provide supplies to students in Makassarese language skills on the one side and the character building on the other side. Furthermore, this study aimed to develop Makassarese language learning materials in elementary school that integrates the characters values. This research was conducted in Makassar city with 14 sub-district as the population and 4 sub-disctrict as the sample. Then the researchers determined 4 school from 4 districts from urban and sub-urban area as research location. The steps of research and development by Borg and Gall and collaborated with the research phase by Brown were refers to produce Makassarese language textbooks based on character building concept. Result of this research produce 8 themes that extracted from 18 character values (character building concept) by Ministry of Education and Culture as follows: Heroism, Historical Place, Citizenship, Family, Motivation, Fine Arts, Religious and Public Place.
\end{abstract}

Keywords: Research and Development, Elementary School, Learning Material, Character Building Concept

\footnotetext{
Abstrak

Siswa sekolah dasar merupakan aset bangsa Indonesia yang sangat berharga untuk dijaga dan dikembangkan dengan nilai-nilai karakter positif yang berasal dari lingkungan keluarga, sekolah, masyarakat dan Indonesia. Penanaman karakter bagi generasi muda saat ini

${ }^{1}$ Presented in The $1^{\text {st }}$ International Conference on Elementary School Teacher Education (ICESTE) organized by Elementary School Teacher Education Department Universitas Negeri Jakarta in cooperation with RMT University, University Plymouth, The Ohio State University and University of Swaziland on October 12-13 2015 in Jakarta, Indonesia.

2 (i) https:// orcid.org/ 0000-0002-1690-0025. Corresponding auhor: sitti.rabiah@umi.ac.id / sittirabiah25@gmail.com
} 
merupakan hal yang mendesak dan menentukan untuk masa depan bangsa menyongsong generasi emas tahun 2045. Mengingat pada periode ini, generasi yang sekarang berada pada jenjang pendidikan anak usia dini, pendidikan dasar, pendidikan menengah, dan pendidikan tinggi akan memasuki usia produktif yang menentukan peran strategis bangsa ini. Khususnya untuk usia sekolah dasar, kelak mereka yang berusia 6-14 tahun (usia pendidikan dasar) sekarang, akan berusia 39-47 tahun di tahun 2045, dan hal ini berarti mereka akan memasuki masa-masa gemilang perkembangannya. Dalam rangka mengawal generasi emas ini, maka perlu diupayakan pembenahan di sektor pendidikan yang memegang peran penting dalam menyiapkan dan mengarahkan sumber daya manusia yang unggul dan produktif, serta menguasai dan mengembangkan ilmu pengetahuan, teknologi, dan seni yang dibutuhkan di era persaingan global. Salah satu cara yang dapat dilakukan yakni mengintegrasikan nilai-nilai karakter ke dalam bahan ajar Bahasa Makassar. Bahan ajar ini diharapkan dapat memberikan bekal kepada siswa dalam kemampuan berbahasa Makassar di satu sisi dan pembentukan karakter di sisi yang lain. Lebih lanjut, penelitian ini ditujukan untuk mengembangkan bahan ajar Bahasa Makassar di sekolah dasar yang mengintegrasikan nilai-nilai karakter. Penelitian ini mengacu pada langkah-langkah penelitian dan pengembangan (Research and Development) dari Borg dan Gall, serta dikolaborasikan dengan fase penelitian dari Brown hingga menghasilkan buku ajar bahasa Makassar berbasis karakter.

Kata Kunci: Penelitian dan Pengembangan, Sekolah Dasar, Bahan Ajar, Bahasa Makassar, Pendidikan Karakter

\section{Introduction}

Elementary school students is an asset of Indonesia which is valuable and will determine the fate of the nation in the future. In 2045, Indonesia will enter a period of 100 years of independence and the student is expected to have a superior ability and good character. In the same year, Indonesia will experience a demographic bonus periodicity, i.e. children aged 3-5 years (early children education program age) will be aged 36-38 years, those aged 6-14 years (elementary school age) turns 39-47 years, those aged 15-17 years (junior high school age) will be 48-50 years old, while those aged 18-21 years (high school age) will be aged 51-54 years old. Minister of Education and Culture (MEC) asses in their ages now, tomorrow they will hold a strategic role in the country because they are in the productive ages. (http://www.pikiranrakyat.com/node/186763).

Efforts to form a golden generation can be done one of them through the education sector. This sector plays an important role in setting up and directing the superior and productive human resources, beside that they should mastery and develop science, technology, and art is needed in this global competition era. According to Sri Edi Swasono (2012: 5-6), the basic task of education should be "educate the nation". In this conception of educate the nation is not the only means to educate the people intellectual.

In this context, education is not only aimed to fight the social ignorance, but also the social backwardness. By educating the nation means, we seek to improve the quality: piety to God, science literacy, social, art and culture literacy, civilization, awareness of history, geography and spatial, ideology, unity, togetherness, and mutual 
cooperation (populist), solidarity, the mastery of science and technology, sovereignty, independence, dignity, equality, modernization, courage and honesty, and humanism. From this conception, it is clear that the educating the nation actually cannot be separated from the concept of nation and character building, which builds character and civilization of national life.

Seeing the urgency of the character building through education, as well as the potential of periodization of elementary school age who will hold a strategic role for the nation. There should be an truly effort to do development at the elementary school level. One of them through research and development in elementary schools. Subjects to be studied further in this paper is Makassarese language which have positions as local content in Makassar city.

Moreover, education is also not forgotten the formation of character building concept needs should be integrated with school subjects with a variety of interesting ways that systematically and in accordance with the characteristics of child development, in this case the elementary school age. One way to do that is to integrate character values into the learning process. In this paper, the author will integrate the values of characters into language learning materials of Makassarese languge.

Makassarese language is one of the local languages in South Sulawesi. The learning process of Makassarese language was prepared with the objective that the students have: (1) Makassarese language skills both oral and written, (2) a good knowledge of the Makassarese language and literature, (3) a positive attitude towards the Makassarese language, literature, script, and the culture.

The learning process is expected to provide supplies to students both Makassarese language skills on the one hand, and the character building on the other. So that the values of these characters will undergo internalization into the Makassarese language learning process in elementary school students.

Furthermore, the urgency of this study refers to the efforts to realize golden generation in 2045 by optimizing the character building values to elementary school students through Makassarese language learning, so that they can be the generation that can be relied upon in the future as a guard forefront of the development of Indonesia. The innovation of this study is Makassarese language learning materials that integrate the values of characters are expected to support student learning in school, as an embodiment of the role of education in producing a golden generation of intelligent and competitive.

\section{The Model of Research and Development in Elementary School}

The model is a conceptual framework that describes systematic procedures to organize learning experiences to achieve specific learning objectives in the form of series of learning approaches, strategies, methods and techniques. In other words, the learning model is a wrap or frame from the application of learning approach, methods, and techniques. If the learning approaches, strategies, methods, techniques and already 
elaborate as one comprehensive thing, then this elaboration what we call it learning model.

If it is associated with the development model of Makassarese language learning material as the concept that being developed to produce learning material based on the needs analysis towards elementary school students as the production target. In the learning development model model by Borg and Gall serve as a guide or reference to develop the concept/basic framework of a systematic learning model. In addition, the authors also adopted a model by Brown related to the development phase model of learning materials that are classified into three main phases namely: development, implementation, and evaluation.

\section{Model of Research and Development by Borg and Gall}

Research and Development (R\&D) can be simply defined as the research methods used to produce a particular product and effectiveness test of the product. From this definition, research and development has implications on two main points, namely: product and effectiveness. Research and development is defined as a process or steps to develop a new product or improve existing products, that can be accounted. Besides that R\&D can also be defined as a process to produce $100 \%$ new and modification event innovative products that exist but have the authenticity, validity and reliability through the process with criteria and scientific standards with repeatedly.

Related to the complexity of the mechanisms and measures of research and development in the field of education Borg and Gall (2003: 542-543) states there are ten steps in an implementation of research and development in the field of education, among others: (1) need analysis, (2) planning, (3) developing a preliminary form of the product, (4) preliminary field testing, (5) revising the main product, (6) playing field testing, (7) operational product revision, (8) operational field testing (9) the final product revision and (1) dissemination and implementation. Ten step is a step that serves as a systematic guidance for researchers to produce a model of the development of learning materials. Such steps need to be carried out in stages in order to obtain maximum results and quality.

Related to the complexity of the research and development mechanisms and measures in the field of education by Borg and Gall (2003: 542-543) states there are ten steps in an implementation of research and development in the field of education, there are: (1) need analysis, (2) planning, (3) developing preliminary form of product, (4) preliminary field testing, (5) revising main product, (6) main field testing, (7) operational product revision, (8) operational field testing, (9) final product revision dan (10) dissemination and implementation. The step mentioned above is a step that serves as a systematic guidance for researchers to produce learning materials from the development model. These steps need to be carried out step by step in order to obtain maximum and best quality in results. 


\section{Model by Brown}

Brown (1995: 139-140) suggests the development model of learning materials is a process that involves three main phases, namely: (a) develop instructional materials, (b) learning in the classroom (field testing), and (c) evaluation of instructional materials. The first phase of the development phase consists of activities (a) needs analysis, (b) defining goals and objectives, (c) test the ability of beginning and student characteristics, and (d) preparing instructional materials as a product. Furthermore, the second phase is the implementation phase of learning include (a) teaching and learning in the classroom, (b) a discussion between teacher and author of learning materials, and (c) revision for final repairs, and then the third phase of the evaluation, in this phase includes five case namely: (a) evaluating learning materials, (b) revision of learning materials, (c) generating and designing the learning materials, (d) distribution and publication (internally or externally on a small scale or large), and (e) it should be noted materials teaching never ends at a certain point he is always evolving according to the needs of trends that are highly dependent on the needs of learners at a particular time.

\section{Development of Makassarese Language Learning Materials Based on Character Building Concept in Elementary School}

\section{Position of Makassarese Language}

Before explaining further about the Makassarese language learning materials, first let me explain the position of Makassarese language. This language serves as regional language. The position is based on the fact that the local language into the language of instruction and the connections between speakers of the regional language and culture as well as supporting the community and society generally in South Sulawesi province, specifically in Makassar city. This can be seen in the depiction of the Makassar people, which is in the tradition of attitudes, and language is what distinguishes it from other public entity. Although in many writings, community groups called Makassar tribes. Nonetheless, broadly in society, both major tribes living in South Sulawesi, the Bugis and Makassar tribes, more commonly incorporated into the Bugis-Makassar. In fact, it is not much of a difference, which is prominent only in the language it uses. Therefore, the designation of Makassar society is more often associated with the speakers of the regional language. (Wahid, 2007: 27-28)

According to Alwi and Sugono (2003: 40), the position of the regional language should be viewed from two perspectives: (1) the regional language as communication tool for the speakers who come from the same ethnic group, and (2) the regional language related to Indonesian language. If viewed from the position that mentioned in the first, regional language serves as: (1) the symbol of the pride of the region, (2) the interface in the family and local communities, (3) a means of supporting regional and Indonesian cultures and (4) supporting regional and Indonesian literature. However from the four from five functions mentioned above has not gone as expected. 


\section{The Concept of Character Building}

Referring to the Rule of Character Education Development by the Ministry of Education and Culture (MEC), basically teaching character education in the principles covered as follows: (1) promote the basic ethical values as the basis of character, (2) identifying characters in a comprehensive manner that includes thoughts, feelings, and behaviors, (3) using a sharp approach, proactive, and effective way to build character, (4) provide opportunities for learners to demonstrate good behavior, (5) the scope meaningful and challenging curriculum that respects all learners, build their character, and helps them to succeed, and (6) promoting the growth of self-motivated learners. (Asmani 2011: 56-60)

Learning system design consists of four components that have a functional relationship and intertwined with each other between the learning materials, learning competencies, learning strategies, and evaluating learning. Learning strategy which is the third link that connects between the subject matter and the competence of a material. So the things that should be taken into consideration in the development of teaching materials.

Based on the statement from Barnawi and M. Arifin (2012: 66-68) and input from MEC (2011:13). The authors in the development of Makassarese language learning material implement integration strategies by integrating the values and characters into part of the learning material. From the explanation above, it can be concluded that the integrated character education is the introduction of values, gained awareness of the importance of values and the internalization of values into the behavior of everyday learners through the learning process, both inside and outside the classroom on all subjects, including Makassarese languages. Integration of character education on subjects leads to the internalization of values in everyday behavior through the learning process of the stages of planning, implementation, and assessment. This is consistent with the pattern of development by MEC learning model, known by the acronym ICARE (Introduction, Connection, Application, Reflection, and Extension).

\section{The Values of Character}

As has been noted previously that basically character education can be developed through the learning process in an integrated manner. Following further exposure related to the values of character can be developed in learning process.

Fathul Muin (in Barnawi and M. Arifin, 2012: 27) states that it is essentially important pillar of the human character consists of six terms of which is as follows: (1) respect; (2) responsibility; (3) citizenship-civic duty; (4) justice and fairness; (5) concern and willingness to share (caring); (6) trustworthiness.

Furthermore, the MEC identified 18 values derived from religion, Pancasila, culture and national education goals, namely: (1) Religious, (2) Honesty, (3) Tolerance, (4) Discipline, (5) Work hard, (6 ) Creative, (7) Independent, (8) Democratic, (9) Curiosity, (10) The spirit of Nationality, (11) Patriotism, (12) Rewarding Achievement, 
(13) Friendly/Communicative, (14) Love Peace, (15) Joy of Reading, (16) Environmental Care, (17) Social Care, and (18) Responsibility (Curriculum Center, 2009: 9-10 in Kemdikbud Director General of Basic Education, 2011: 26-27).

Based on the above guidelines, then it should be the development of learning materials based on character values can refer to aspects of these objectives, so that the result of learning materials can achieve the expected goals lead generation and character.

\section{Philosophy of Elementary School Students}

The philosophy of elementary school of fifth grade students from this research based on the consideration that their ages ranged between 11-12 years. With a target implementation, learning materials produced will be used by students at this age category. The reason for choosing this category being targeted, if considered age, learning the language at this age are included in the operating of concrete operational period (Singer and Revenson, 1996: 22-25). The introduction of the characteristics of elementary school students is very important because it affects the components is done in the framework of the research, as well as the development of learning materials, such as needs analysis, the type of test is given, as well as the selection of the content and topic learning materials developed.

\section{Steps of Learning Material Development}

After pass the series of stages of learning model development is done with careful measures referring to the concept model was developed along with references about character values. Then drafted learning materials that have been developed based on research results. As the concept of the research and development (R\&D) model, the learning materials development should be based on research process and then do development process.

Research on the learning materials developed are briefly started with targeting and then next in the school target, researcher conducted a needs analysis which consists of filling out the questionnaire related to some aspects to be studied and related to the development process and the implementation of a preliminary test (pre-test). In addition, researcher are also analyze the teaching method from the school teachers and expectations from school principal. Furthermore, researcher formulate data collected from students, teachers, and principals then shaped data tabulation and analyzed.

The questionnaire of need analysis for students include places when Makassarese language use to measure students' understanding of character values that have been developed in the community. Then a questionnaire for teachers and principals focused on the expected outcomes of learning the language, as well as the efforts made by teachers to character values in students.

Following exposure to the needs analysis related to character values. Questionnaire of students found a misperception of the term that is often heard in the 
community such as, Ewako! which means spirit, it is defined negatively by the students in the questionnaire so that the results of $45 \%$ (58 of 129 respondents) disagreed with the statement. Though the word is part of the character values . Furthermore, the questionnaire of teachers stated that the indirect method to enter character values into teaching materials integrated into option 3 of the 4 teachers. It shows that this study is a solution for teachers to develop the character of students. Then the principal's questionnaire found that two schools is still limited to using attributes to instill character values, while 2 other schools already had a meeting with the teachers to equate the views associated means instill character values (Questionnaire and Interview Results, May 2014).

Then from the results of the analysis of the needs of students, teachers and principals defined common goal of learning as follows: (1) reading skills: able to understand the information through reading in the local language, (2) speaking skills: able to give information about something, such as conversing in community, and express ideas in the local language, (3) listening skills: able to listen to the information verbally over the day-to-heart conversations and electronic media, (4) writing skills: able to express ideas in the local language, and can translate a Lontarak script into Makassarese and Indonesia languages, (5) vocabulary: can understand and use the vocabulary of the local language in daily activities, (6) the structure of language: Makassarese language structure can use in oral and written.

After do the steps above, then the researcher have been able to design a model of learning materials were developed. Researcher can start with a simple structure that led to the final draft. In the initial development process is structured such things as the syllabus and learning materials prototype that cover the main parts, and determine the theme of each part in learning materials.

After completing the preliminary design process of learning materials developed, then proceed with testing of instructional design expert and Makassarese language content expert. After that, the input from the experts can be used as a reference for designing the final model of learning materials developed. Once the model is considered final, then tested the feasibility and readibility on learning materials are carried out on an experimental class students were determined. The structure of learning models developed can be seen in Figure 1. 


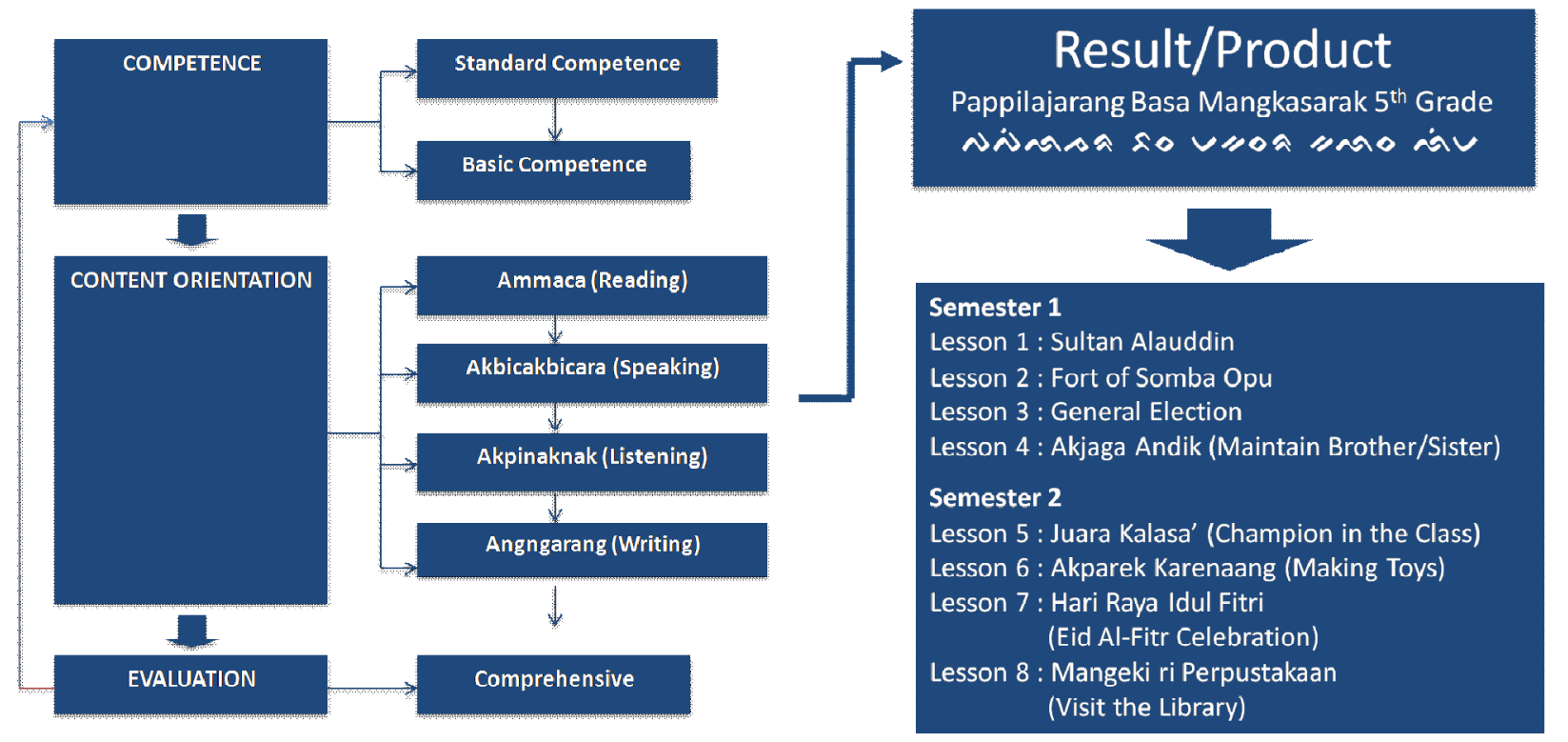

Figure 1. Learning Materials Model "Pappilajarang Basa Mangkasarak" for Fifth Grade Elementary School

\section{(1) Competence}

This section consists of standards competence and basic competence are abbreviated with SC/SK and BC/KD. SK contains general objectives to be achieved by the students of the learning process that took place in each section called 'Lesson'. Furthermore KD contains the specific purpose of learning that associated with indicators of student achievement towards learning process.

\section{(2) Content Orientation}

This section consists of a learning component that will involve students and teachers. Learning materials are used only as a guideline and direction in determining the discussion at each meeting. However, the learning process will largely depend on the activity and the ability of students and teachers to explore further this learning material used.

(a) Ammaca (reading), this activity of reading material is provided in the form of text and dialog. Furthermore, at the end of each text/dialog there is a new vocabulary and questions based on the themes discussed.

(b) Akbicarabicara (speaking), this activity there is many of speaking skills to sharpen student ability and increase confidence in using the Makassarese language.

(c) Akpinaknak (listening), this activity required the creativity of teachers to present stories related to the themes discussed, then the teacher read the story to the students.

(d) Angngarang (writing), this activity consists of three types of activities in this learning material i.e the use of the word structure, translating aksara lontarak, 
and writing stories. This activity sharpen the students' writing skills, and improve the understanding to convey their ideas through writing.

\section{(3) Evaluation}

At the end of each lesson, an evaluation of the learning process has been held. This is to measure students' understanding of the material that has been taught. In this evaluation used a comprehensive evaluation involving the four language skills i.e. reading, speaking, listening, and writing.

Furthermore, Pappilajarang Basa Mangkasarak above is divided into two parts which are classified based on Semester 1 and Semester 2. Each semester consists of 4 lessons with total 8 lessons in one learning materials. The learning material has been fitted with the goal of character education that refers to the 18 values that have been identified by the Center for Curriculum MEC. The values sourced from religion, Pancasila, culture and national education goals of these values was elaborated into the topics taught in the learning material. The design is as follows:

1) Sultan Alauddin (Heroism) - A model of hero which perform a good character as religion followers and have a strong committment to his country as a citizen.

2) Benteng Somba Opu (Historical Site) - A Battle field to defend kingdom territory (nationalism and patriotism).

3) Pemilu / General Eelection (Citizenship) - A reflection of democratic practice in Indonesia.

4) Akjaga Andik/ Sitting for Younger Brother/Sister (Family Live) - Teaching resonsibility as a family member.

5) Juara Kalasa'/ School Champion (Motivation) - Teach students to appreciate hardwork and appreciation.

6) Akparek Karenaang/ Making Toys (Crafting) - Teach student to be more in dependent in producing their own games.

7) Hari Raya Idul Fitri/Religion Event Celebration (Religion) - Improve student understanding to the religion they embraced and how to be more tolerant to other religion groups.

8) Mangeki ri Perpustakaan/ Library Visit (Public Place) - Introduce students to the reading behavior by understanding the benefit of public library.

Based on the explanation above, it can be understood that research and development in elementary school in Makassarese language learning materials consist of a series of characters based on a preliminary survey process, need analysis to the learning materials development with a series of test. Outcomes from this study that the drafting of learning materials of " Pappilajarang Basa Mangkasarak" / Makassarese Language Learning for Fifth Grade Elementary School Student. The concept of 
character education becomes an important aspect in this study is inserted by integrating it into learning materials on topics associated with the character value adjusted.

\section{Conclusion}

Research and development in elementary schools is an effort to develop products through the stages of research then the outcomes in a form of development product on completely new product or modified product. Research and development conducted in Makassarese language learning materials based on character building concept is one example of the application from methods of research and development introduced by Borg and Gall combined with Brown model.

Stages of research and development which consisted of a preliminary survey, needs analysis to the learning materials development are an inseparable unity. These steps must be followed systematically in order to produce high quality learning materials and can implementing on production target, in this case the fifth grade of elementary school students.

The research and development efforts of learning materials at elementary school level is not only apply to one of the subjects, but are open to all subjects. Obstacles that may be encountered in this process is the ability of developers/researcher to explore the content of learning materials offered in the learning process, in addition also have to understand the development of the methods used in their entirety.

Character education is also a bargaining position in learning materials is a necessity, that all learning materials geared to build the character of the nation. This efforts adapted from the government's program in education at the national level that promote character education as one of the pillars to form the golden generation in 2045. In research and development, the way to integrate the character values into learning materials in accordance with the opinion of Barnawi and Arifin and input from the Ministry of Education as a stakeholder in the field of education.

\section{Acknowledgement}

The researcher would like to acknowledge the Directorate General of Higher Education, Ministry of Research, Technology and Higher Education, Indonesia on research funding has been awarded through a Hibah Bersaing scheme in the second year. Hopefully, this study provides a positive contribution to the efforts to develop local languages in Indonesia.

\section{References}

Alwi, Hasan dan Dendy Sugono. 2003. Politik Bahasa Nasional. Jakarta: Pusat Bahasa. Asmani, Jamal Ma'mur. 2011. Buku Panduan Internalisasi Pendidikan Karakter di Sekolah. Yogyakarta: Diva Press. 
Barnawi dan M. Arifin. 2012. Strategi dan Kebijakan Pembelajaran Pendidikan Karakter. Yogyakarta: Ar-Ruzz Media.

Borg, Walter R. dan Meredith Damien Gall. 2003.Educational Research: An Introduction Seventh Edition. Boston: Allyn and Bacon.

Brown, James Dean. 1995. The Elements of Language Curriculum: A Systematic Approach to Program Development. Boston: Heinle\&Heinle Publisher.

Halim H., Abd. 2007. Pengembangan Model Bahan Ajar. Jakarta: Pustaka Press.

Joyce, Bruce, Marsha Weil, dan Emily Calhoun. 2009. Models of Teaching: ModelModel Pengajaran edisi delapan diterjemahkan Achmad Fawaid dan Ateilla Mirza. Yogyakarta: Pustaka Pelajar.

Kementerian Pendidikan dan Kebudayaan. 2011. Pembelajaran Kontekstual dalam Membangun Karakter Siswa. Jakarta: Kemdikbud.

Mulyana, E. 2003. Kurikulum Berbasis Kompetensi, Konsep, Karakteristik, dan Implementasi. Yogyakarta: Remaja Rosdakarya.

Pikiran Rakyat. 2012. Hardiknas 2012, Bangkitnya Generasi Emas Indonesia. http://www.pikiran-rakyat.com/node/186763.

Pribadi, Benny A. 2010. Model Desain Sistem Pembelajaran. Jakarta: Dian Rakyat.

Rabiah, Sitti. 2012a. "Model Bahan Ajar Bahasa Makassar sebagai Muatan Lokal: Penelitian dan Pengembangan di Sekolah Dasar kota Makassar". (Disertasi), Universitas Negeri Jakarta.

Rabiah, Sitti. 2012b. Revitalisasi Bahasa Daerah Makassar melalui Pengembangan Bahan Ajar Bahasa Makassar sebagai Muatan Lokal. Dipresentasikan dalam Kongres Internasional II Bahasa-Bahasa Daerah Sulawesi Selatan Tahun 2012. Makassar: Balai Bahasa Provinsi Sulawesi Selatan dan Provinsi Sulawesi Barat. doi: 10.31227/osf.io/bu64e

Rabiah, Sitti. 2013. Pengembangan Materi Ajar Bahasa Makassar berbasis Nilai-Nilai Karakter dan Kearifan Lokal di Sekolah Dasar Kota Makassar. Dipresentasikan dalam Konferensi Internasional Budaya Daerah. Sukoharjo: Ikatan Dosen Budaya Daerah Indonesia. doi: 10.31227/osf.io/s8uv5

Rabiah, Sitti. 2014. "The Learning Model of Makassarese Language Based on the Character Building Concept: Research and Development in Elementary School of Makassar City" (Proceeding of International Seminar on Languages and Arts), Faculty of Languages and Arts, Universitas Negeri Padang. doi: 10.31227/osf.io/en63f

Singer, Dorothy G. dan Tracey A. Revenson. 1996.A Piaget Primer: How a Child Thinks Revised Edition. New York: Plume.

Sumardi. 2000. Buku Pelajaran Bahasa Indonesia SD sebagai Sarana Pengembangan Kepribadian, Penalaran, Kreativitas dan Keterampilan Berkomunikasi Anak. Jakarta: Grasindo. 
Tomlinson, Brian. 2007.Developing Materials For Language Teaching. London: Continuum.

Trianto. 2011. Mendesain Model Pembelajaran Inovatif-Progresif: Konsep, Landasan, dan Implemetasinya pada Kurikulum Tingkat Satuan Pendidikan (KTSP). Jakarta: Kencana, 2011.

Wahid, Sugira. 2007. Manusia Makassar. Makassar: Pustaka Refleksi. 